\title{
Personal Bankruptcy in the Czech Republic: Age and Gender of the Debtors and Structure of the Creditors
}

\author{
Jan Hospodka - Ondřej Buben - \\ Monika Randáková - Jiřina Bokšová*
}

\begin{abstract}
:
This paper analyses debtors who applied for debt relief in the period between $1 / 1 / 2012$ and 31/12/2013. As there has already been a research related to Moravian and Silesian regions in this matter, it focuses mainly on the debtors from Bohemian regions. It is therefore an analysis of a problem which has not been thoroughly covered nor published yet. New way of declaring bankruptcy, in other words debt relief, for debtors who are unable to repay their debt has been in action since 2008 . Since then the number of personal bankruptcies has been gradually rising every year. This paper constitutes only a narrow section of broader research; therefore, only certain characteristics are covered. Those are age and gender of the debtors and the structure of the creditors in all of the regions. The results and information gathered during the research are being analysed and also compared among particular regions.
\end{abstract}

Key words: Bankruptcy; Debtors; Czech Republic.

JEL Classification: G33, K35, M41.

\section{Introduction}

Personal bankruptcy and the possibility for debtors who are unable to repay their debt to undergo a debt relief is a result of new legislation which has been in action since 2008. Inspiration for this change has come from abroad, Germany and USA in particular (Frelichová, 2008).

Jan Hospodka; University of Economics in Prague, Faculty of Finance and Accounting, Department of Financial Accounting and Auditing, W. Churchill Sq. 4, 13067 Prague 3, Czech Republic, <xhosj00@vse.cz>.

Jiřina Bokšová; University of Economics in Prague, Faculty of Finance and Accounting, Department of Financial Accounting and Auditing, W. Churchill Sq. 4, 13067 Prague 3, Czech Republic, <boksova@vse.cz>.

Monika Randáková, University of Economics in Prague, Faculty of Finance and Accounting, Department of Financial Accounting and Auditing, W. Churchill Sq. 4, 13067 Prague 3, Czech Republic, <randakm@vse.cz>.

Ondřej Buben, University of Economics in Prague, Faculty of Finance and Accounting, Department of Financial Accounting and Auditing, W. Churchill Sq. 4, 13067 Prague 3, Czech Republic, <xbubo00@vse.cz>.

The article is processed as an output of a research project number F1/100/2014 with the assistance of the Internal Grant Agency of the University of Economics in Prague. 
Hospodka, J. - Buben, O. - Randáková, M. - Bokšová, J.: Personal Bankruptcy in the Czech Republic - Age and Gender of the Debtors and Structure of the Creditors.

Article focuses solely on debtors who were successful with their application and whose proposal was successfully approved by the appointed court. There has already been a research conducted on this topic focusing primarily on Moravian and Silesian regions (Paseková, 2013b). The results of this research have shown a certain tendency regarding the age and gender of the debtors. However, in her research only 109 debtors were analysed. This paper therefore provides the reader with detailed analysis of certain characteristics of the debtors in bohemian regions and gives insight into their demographics and their creditor structure and at the same time covers considerably larger number of debtors. It also reflects the outcomes of other research on debt relief and compares the results. This paper on the hand does not cover the reasons for which the individuals filed for their personal bankruptcy as this research focuses on their characteristics rather than their story, as for example the research conducted in Lithuania by Arvydas Paskevicius and Neringa Jurgaityte (2015). It is also very important to note that this paper and the whole research does not cover what happens to the debtors after the debt relief is successfully approved. That topic has already been covered in other research abroad as well as in the Czech Republic. For example, Randáková and Bokšová (2015) examine the ratio of successfully repaid debts in the process of debt relief and discovered considerably positive findings, such as that more than $50 \%$ of debtors manage to repay $100 \%$ of their debt. From a different perspective, Jagtiani and Li (2015) analyse the availability of credit to debtors who filed for bankruptcy in US.

Since other regions have already been covered in other research, the aim of this article is to cover the rest of the country, in other words, bohemian regions. There are nine regions in total, as follows:

- Prague,

- Středočeský Region,

- Jihočeský Region,

- Plzeňský Region,

- Karlovarský Region,

- Ústecký Region,

- Liberecký Region,

- Pardubický Region,

- Královéhradecký Region.

Applications for debt relief are submitted to a local regional court. Therefore, collecting and analysing the data was divided into regions to be able to detect and observe any anomaly that might appear with possibility of specialization on a region if the results were considerably different between these regions. As there is not a regional court in every region and some of the regions therefore belong under the same court, it is not possible to analyse and compare the data from all 
the regions. This concerns mainly Plzeňský and Karlovarský regions, which both belong under the same regional court in Plzeň. Another reason to observe regions separately is the differences in wage and cost of living such as renting an apartment, commuting to work, public transport as well as employment opportunities. (Roback, 1988).

As it has already been stated above, this paper presents a research which related to the characteristics of debtors regarding their age, gender and structure of their creditors. The uniqueness of the research is based primarily on the number of debtors who are being analysed, which gives the outcomes high credibility. In the opinion of the authors, it is very important to understand who are the people applying for the personal bankruptcy to be able to come with relevant solutions to their situation and help prevent such cases in the future.

\section{Debt relief}

As already mentioned above, personal bankruptcy, debt relief is a form of bankruptcy. In comparison to normal bankruptcy is debt relief meant to allow the debtors to be forgiven a part of their debt and also reschedule their payments in order for them to be able to manage their debts and in the end be given a fresh start in their life. In order to achieve this, the debtors firstly need to meet certain conditions. Their debt must be at least 30 days overdue and at the same time the debtor must be unable to repay their debt and have at least two or more creditors (Smrčka, 2011). It is also important to mention that the possibility of undergoing personal bankruptcy is primarily meant for non-business entities, of which vast majority are individuals, not NGOs. However, based on a decision of the High Court in Prague, since 2010 it is also possible to be allowed to undergo debt relief even with a part of the liabilities coming out of business operations, if the creditors agree to do so. It is also very important for the debtor to truthfully describe how did they end up in their current situation and they also need to prove that they will be able to repay at least $30 \%$ of their debt. That is the minimum part of their liabilities they need to pay for the debt relief process to successfully finish.

After the Court assesses the personal bankruptcy application and approves of it, the debtor is then protected against any new interest and penalties coming out of their existing debts. Each of them is assigned with a bankruptcy administrator who from that moment oversees the economic activity of the debtor and the whole insolvency process. It is very important to take into account that personal bankruptcies may have significant impact on debtor's life. A study in Canada presented a correlation between undergoing a personal bankruptcy and health. As a particular example the study mentions soaring number of acute myocardial infarction (also known as heart attack) of individuals who are undergoing debt relief process (Savu, 2016). 
Hospodka, J. - Buben, O. - Randáková, M. - Bokšová, J.: Personal Bankruptcy in the Czech Republic - Age and Gender of the Debtors and Structure of the Creditors.

There are two methods of debt relief process. A minority of debtors repay their debts by monetizing their assets and afterwards using the yields to satisfy their creditors. However, a vast majority of debtors chose the second option, which consists of repaying the debt through a repayment plan. This repayment plan takes up to five years during which all earning of the individual are limited to a subsistence minimum and all the rest is collected by the bankruptcy administrator and distributed to the creditors. Even though five years might seem as a very soft measure, in some of the other countries the lengths of repayment plans tend to be even longer. "A personal bankruptcy in Ireland lasts for 12 years, and in Germany six years, during which the debtor's rights are few and the law gives the creditor all the levers to extract as much money from the debtor as he can." (Draghici, 2015). Both methods can be however combined if there is a chance of higher satisfaction of the creditors (Hásová, 2013). If the debtor manages to repay the whole debt before the end of their repayment plan, the plan could also take less time.

This paper poses two hypothesises. Firstly, that "the mean age of the debtors is lower than the adjusted mean age of the entire population in each region". Secondly, that "most common age group of debtors are individuals between 35 to 44 years old." In prior phases of the research on personal bankruptcies in the Czech Republic, on which this paper is partially based, it has been discovered that in the South Bohemian region, which was one of the two regions analysed for $100 \%$ of the debtors and used to set a valid sample for the rest of the Czech Republic, the mean age of the debtors was 44.64 years. (Hospodka et al, 2014). We consider it therefore safe to assume that a similar result will be obtained from all the other regions in the $10 \%$ sample, as average age in all the analysed regions for the population between 18 to 99 years old was slightly above 47 years as at 1.1.2014. This will be further supported by statistical tests conducted in the following chapters.

Regarding the second hypothesis, this age group tends to earn more money because of more experience and better position on the job market, however also to have a family or other reasons for higher expenditures. It is also very important to mention that this age group is very significant when it comes to age distribution of the whole population of the Czech Republic and it is only logical, that their presence among debtors would be equally significant. Also, previous research on this topic presents this group as the most frequent one (Paseková 2013a).

\section{Sample selection}

For many years in a row, the number of proposals for debt relief, which have been submitted to the court, has been growing around $30 \%$ each year. There are several explanations to that. Firstly, there is still a very limited financial literacy among 
population, especially the older part of it. Secondly, the total amount of debt being lent to households has soared since the year 2000, as is illustrated by Figure 1.

\section{Fig. 1 Development of Loans to Households in the Czech Republic (in bil. CZK)}

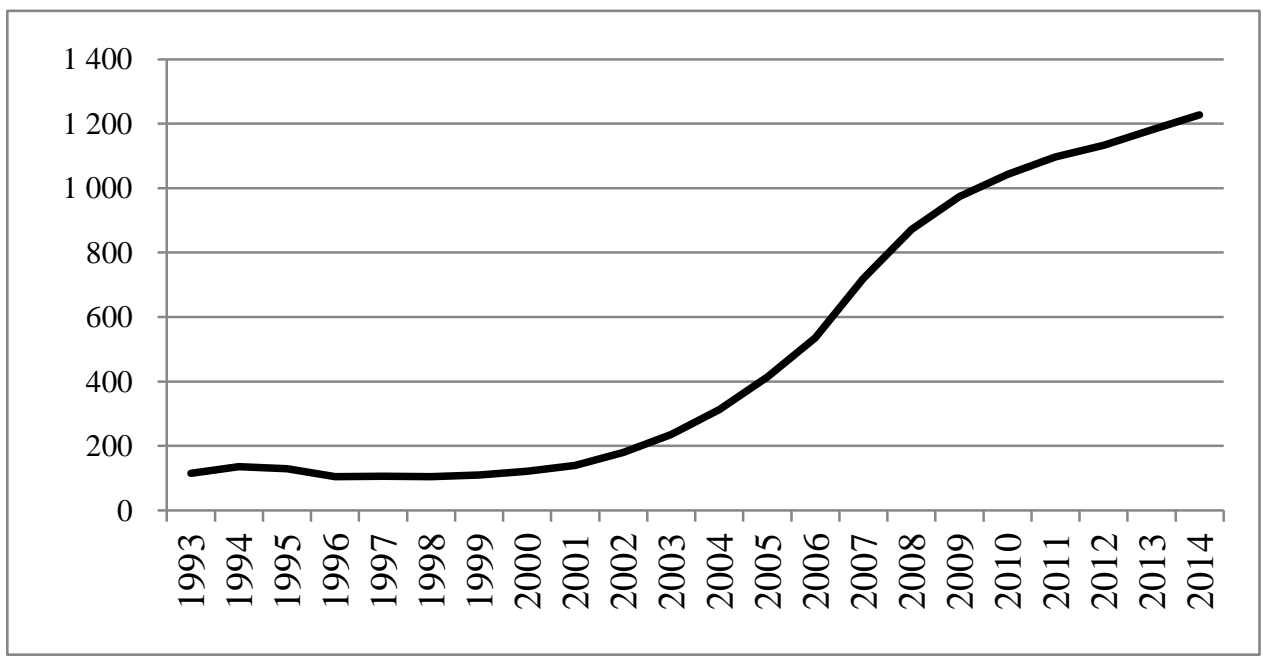

Source: Czech National Bank, 2016.

There were over thirty-four thousand individuals registered under Insolvency Register proposing for personal bankruptcy in the reporting period between 2012 and 2013 in all the regions. As it is not possible to automatically process data from the register and it was necessary for each examined debtor to find their proposal and the information then enter into a database for further analyses, a sample of $10 \%$ was selected as an appropriate proportion and within the capacity of researchers. During research itself, firstly debtors were examined whether they had successfully proposed for debt relief or not. Secondly, if they did, they were further investigated for more information such as age, gender, net monthly income, the total amount of debts and structure of creditors. The following table shows number of all debtors registered under each region in reported period for personal bankruptcy as well as amount of those debtors in $10 \%$ sample and number and proportion of successful proposals for debt relief.

In the previous research, in a few regions a 100\% sample was obtained and from the data a $10 \%$ sample was suggested as a sample which provides precise and correct results similar to $100 \%$ sample. Every tenth debtor has been analysed and the debtors were arranged and lined in terms of date of their first application. To ensure the relevance of $10 \%$ sample, the obtained data from $100 \%$ region were divided into ten same-sized samples and then compared. The differences among 
Hospodka, J. - Buben, O. - Randáková, M. - Bokšová, J.: Personal Bankruptcy in the Czech Republic - Age and Gender of the Debtors and Structure of the Creditors.

samples were under 5\% in each observed part such as gender, age structure, creditors and also amount of debt and income.

Tab. 1 Sample of debtors in regions

\begin{tabular}{llllll}
\hline Region & $\begin{array}{l}\text { Number } \\
\text { of } \\
\text { debtors }\end{array}$ & $\begin{array}{l}\text { 10\% sample } \\
\text { of debtors }\end{array}$ & $\begin{array}{l}\text { Successful } \\
\text { proposals for } \\
\text { debt relief }\end{array}$ & $\begin{array}{l}\text { Success } \\
\text { rate (in \%) }\end{array}$ & $\begin{array}{l}\text { Proportion of } \\
\text { examined } \\
\text { debtors (in \%) }\end{array}$ \\
\hline Prague & 2,389 & 239 & 179 & 75 & 7 \\
Královéhradecký Region & 4,472 & 448 & 370 & 83 & 8 \\
Pardubický Region & 2,851 & 286 & 230 & 80 & 8 \\
Plzeňský Region & 6,359 & 636 & 527 & 83 & 8 \\
Liberecký Region & 1,926 & 193 & 145 & 75 & 8 \\
Středočeský Region & 5,769 & 577 & 465 & 81 & 8 \\
Ústecký Region & 7,330 & 733 & 632 & 86 & 9 \\
Jihočeský Region & 3,418 & 342 & 284 & 83 & 8 \\
\hline Source: Researh & & & & &
\end{tabular}

Source: Research results.

\section{Methodology}

All the data related to the debtors and creditors were obtained from the Insolvency Register which is being administrated by Ministry of Justice of the Czech Republic. This register contains information about every debt relief application. As all the data are available only in pdf format, it is necessary to manually screen and read all the documents in order to find the desired information. The analysed period was set between 1/1/2012 and 31/12/2013 and only $10 \%$ of all debtors who applied in this period were analysed.

Because some of the debtors applied more than once in the analysed period, certain measures needed to be adopted in order not to bias the results. The list of all the debtors has been cleared of all the debtors who applied more than once leaving only one application per particular debtor in the list. Because of wide focus of the whole research were all the debtors screened for various data related to their demographics. For the purposes of this paper were data about age, gender and structure of the creditors collected and analysed. Creditors were divided into three groups. Banking Institutions, Non-Banking Financial Institutions and a group called Other, which consists of all other entities apart from the two.

\section{Research results}

The aim of the research is to analyse the structure of debtors undergoing the process of debt relief in years of 2012 and 2013 in all regions of Bohemian lands. Moreover, it compares these results from every region among each other. Results presented in this paper focuses on structure of debtors from the perspective of age 
and gender as well as on structure of their creditors. Before moving to mentioned categories, the chart below displays the success rate of proposals for debt relief of each region. The average success rate in these regions is $81 \%$, which is achieved by all regions except for Prague, Liberecký Region and also Pardubický region (even though it is only one percent under the average).

\section{Fig. 2 The proportion of successful proposals (in \%)}

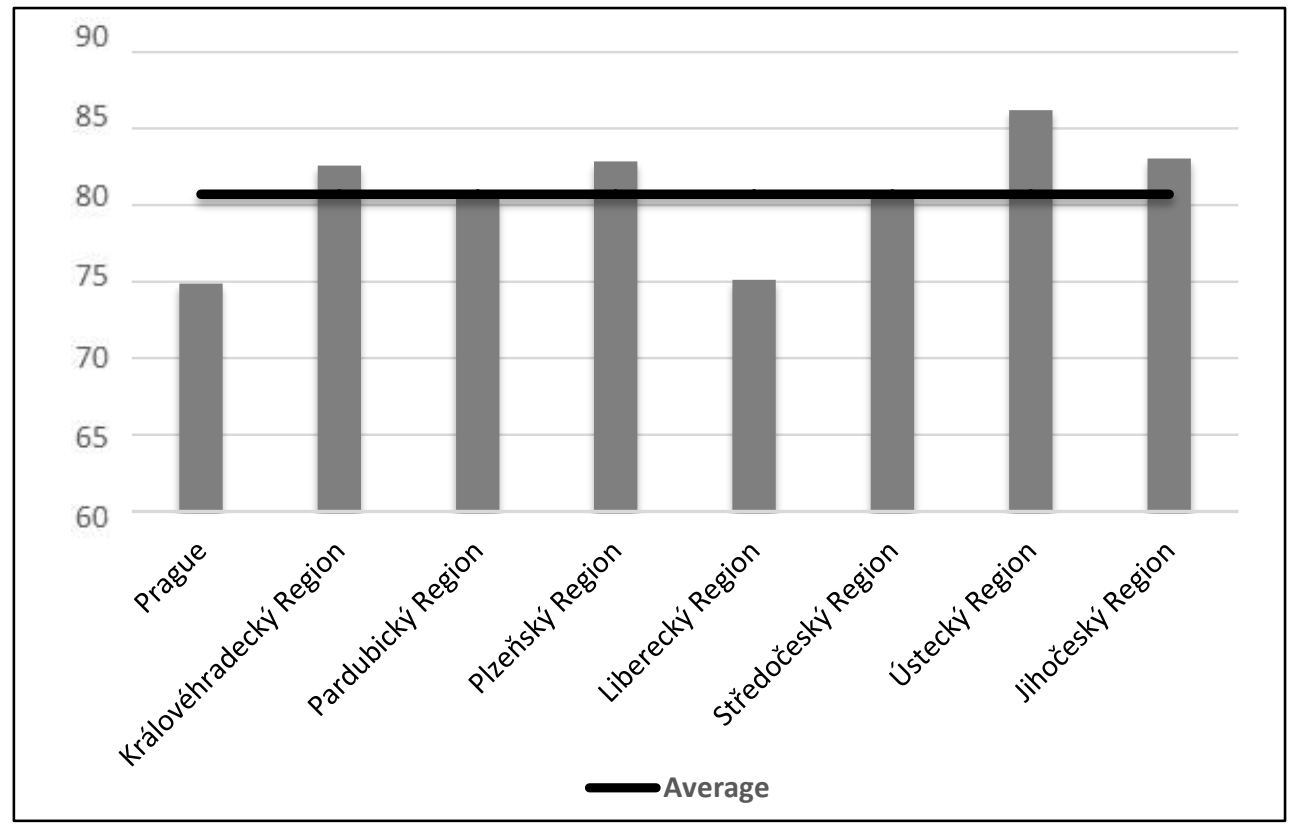

Source: Research results.

If gender structure of debtors in each region is compared to gender structure of residents living in these regions, there are no significant differences except for Prague Region, where the highest proportion of women successfully applying for debt relief in analysed regions and there is also over 8 percentage points more women in the structure of debtors in Prague Region than the proportion of women living in it (see table 2). As it is shown in the table, there are more women proposing for debt relief in most of the regions. However, it does not necessarily mean that women are most likely to be insolvent, because there are more women living in each region and therefore the gender structure of debtors is similar to the gender structure of residents. On the other hand, there is almost $54 \%$ men among debtors in Liberecký Region, although there is over 51\% women living in there. 
Hospodka, J. - Buben, O. - Randáková, M. - Bokšová, J.: Personal Bankruptcy in the Czech Republic - Age and Gender of the Debtors and Structure of the Creditors.

Tab. 2 Gender structure of debtors and population in regions

\begin{tabular}{|c|c|c|c|c|c|}
\hline \multirow{2}{*}{ Regions } & \multicolumn{2}{|c|}{ Men (in \%) } & \multicolumn{2}{|c|}{ Women (in \%) } & \multirow{2}{*}{$\begin{array}{l}\text { Difference } \\
\text { (in p.p.) }\end{array}$} \\
\hline & Region & Debtors & Region & Debtors & \\
\hline Prague & 48.0 & 39.7 & 52.0 & 60.3 & 8.3 \\
\hline Královéhradecký Region & 48.7 & 49.2 & 51.3 & 50.8 & 0.5 \\
\hline Pardubický Region & 49.0 & 50.9 & 51.0 & 49.1 & 1.9 \\
\hline Plzeňský Region & 49.1 & 44.0 & 50.9 & 56.0 & 5.1 \\
\hline Liberecký Region & 48.7 & 53.8 & 51.3 & 46.2 & 5.1 \\
\hline Středočeský Region & 49.0 & 44.3 & 51.0 & 55.7 & 4.7 \\
\hline Ústecký Region & 49.1 & 48.7 & 50.9 & 51.3 & 0.4 \\
\hline Jihočeský Region & 48.9 & 44.0 & 51.1 & 56.0 & 4.9 \\
\hline
\end{tabular}

Source: Research results.

In the following table there is combined gender and age distribution of debtors with focused on age structure of men and women in each region. It is obvious that regardless of gender most of successful proposals for debt relief were submitted by persons aged 35 and over. Especially the group aged between 35 and 44 gathers the largest proportion of people undergoing personal bankruptcy across all regions. This result corresponds to the results of previous research (Paseková 2013b). Therefore, the hypothesis set at the beginning of the research was not rejected and there are several reasons to it. Younger people, primarily those in first age group, are more or less still dependent on their parents or other relatives. Moreover, most of the people taking out a loan really believes they will be able to repay it and it usually takes them a couple of years to realize they are in a trouble and they will not be able to fulfil their commitments, therefore even if debtor takes out a loan in age of 25, it is not likely to propose for debt relief sooner than in five to eight years. Another reason, why most often submitted proposals are by persons aged 35 , is setting up families which can be quite expensive taking into account children and finding larger accommodation and all expenses connected to it. For that reason, over $70 \%$ of all debtors regardless of region or gender are age 35 and over. 
Tab. 3 Age and gender structure among debtors

\begin{tabular}{|c|c|c|c|c|c|c|c|}
\hline \multirow{2}{*}{ Regions } & \multirow{2}{*}{ Gender } & \multicolumn{6}{|c|}{ Age structure (in \%) } \\
\hline & & $18-24$ & 25-29 & $30-34$ & $35-44$ & 45-54 & $55+$ \\
\hline \multirow{2}{*}{ Prague } & Men & 0.00 & 14.08 & 12.68 & 26.76 & 21.13 & 25.35 \\
\hline & Women & 3.70 & 11.11 & 10.19 & 27.78 & 24.07 & 23.15 \\
\hline \multirow{2}{*}{$\begin{array}{l}\text { Královéhradecký } \\
\text { Region }\end{array}$} & Men & 1.10 & 9.89 & 13.74 & 31.87 & 24.73 & 18.68 \\
\hline & Women & 1.06 & 10.11 & 12.23 & 26.60 & 23.40 & 26.60 \\
\hline \multirow{2}{*}{ Pardubický Region } & Men & 3.42 & 11.11 & 13.68 & 33.33 & 25.64 & 12.82 \\
\hline & Women & 4.42 & 12.39 & 12.39 & 18.58 & 29.20 & 23.01 \\
\hline \multirow{2}{*}{ Plzeňský Region } & Men & 1.72 & 11.21 & 16.81 & 28.02 & 22.84 & 19.40 \\
\hline & Women & 2.37 & 11.19 & 12.20 & 25.76 & 23.05 & 25.42 \\
\hline \multirow{2}{*}{ Liberecký Region } & Men & 0.00 & 8.97 & 16.67 & 39.74 & 14.10 & 20.51 \\
\hline & Women & 1.49 & 7.46 & 5.97 & 43.28 & 16.42 & 25.37 \\
\hline \multirow{2}{*}{ Středočeský Region } & Men & 3.40 & 10.68 & 16.02 & 24.27 & 22.33 & 23.30 \\
\hline & Women & 2.32 & 8.11 & 10.04 & 34.36 & 26.25 & 18.92 \\
\hline \multirow{2}{*}{ Ústecký Region } & Men & 0.97 & 8.44 & 11.04 & 33.12 & 22.08 & 24.35 \\
\hline & Women & 1.23 & 8.33 & 8.33 & 26.23 & 26.54 & 29.32 \\
\hline \multirow{2}{*}{ Jihočeský Region } & Men & 3.20 & 12.00 & 9.60 & 31.20 & 23.20 & 20.80 \\
\hline & Women & 1.26 & 8.81 & 13.21 & 25.79 & 25.16 & 25.79 \\
\hline
\end{tabular}

Source: Research results.

To confirm our findings and theories, comparative analysis with age structure of residents of researched regions has been made. As seen in the table below, age group 34-44 is represented at significantly higher rate among debtors than among residents (especially among men), which makes the group even more interesting. Even though the oldest age group has its fair share among debtors, it is way below the proportion of the same age inhabitants in researched regions. On the other hand, the youngest group under 25 is almost negligible among debtors. That is completely understandable, as it usually takes time to gather the amount of debt that would require the debtor to apply for a personal bankruptcy. It is also very common, and logical, for the young people to be financially supported by their parents. 
Hospodka, J. - Buben, O. - Randáková, M. - Bokšová, J.: Personal Bankruptcy in the Czech Republic - Age and Gender of the Debtors and Structure of the Creditors.

Tab. 4 Age structure of debtors and population in regions

\begin{tabular}{|c|c|c|c|c|c|c|}
\hline \multirow{2}{*}{ Age structure } & \multicolumn{2}{|c|}{ Men (in \%) } & \multirow{2}{*}{$\begin{array}{l}\text { Difference } \\
\text { (in p.p.) }\end{array}$} & \multicolumn{2}{|c|}{ Women (in \%) } & \multirow{2}{*}{$\begin{array}{l}\text { Difference } \\
\text { (in p.p.) }\end{array}$} \\
\hline & Residents & Debtors & & Residents & Debtors & \\
\hline $18-24$ & 7.80 & 1.82 & -5.98 & 7.08 & 2.05 & -5.03 \\
\hline $25-29$ & 8.74 & 10.39 & 1.65 & 7.88 & 9.58 & 1.7 \\
\hline $30-34$ & 9.85 & 13.72 & 3.87 & 8.87 & 10.71 & 1.83 \\
\hline $35-44$ & 21.93 & 30.55 & 8.62 & 19.70 & 27.83 & 8.13 \\
\hline $45-54$ & 16.32 & 22.52 & 6.2 & 14.99 & 24.85 & 9.86 \\
\hline $55+$ & 35.36 & 21.00 & -14.35 & 41.48 & 24.98 & -16.49 \\
\hline
\end{tabular}

Source: Research results.

A one sample t-test has been conducted. For this the mean age of debtors in each region was considered and compared to mean age of the population in that region. The mean age of the population in every region was calculated for the whole population in each region between 18 years old and 99 years old. Older inhabitants were not considered as they are only reported as 100+ group and therefore we do not know their exact age. It is also important to say that they were no debtors older than 81 years old. Inhabitants younger than 18 cannot apply for personal bankruptcy and it would be therefore wrong to consider them when calculating the mean age of the population for this purpose. Table below shows a comparison between debtor's structure and population structure in each region using a One-Sample test.

Tab. 5 Age structure of debtors and population in regions - statistical test

\begin{tabular}{llllll}
\hline \multirow{2}{*}{ Regions } & \multicolumn{3}{c}{ Debtors } & Population & \\
\cline { 2 - 6 } & Mean & Std. deviation & Mean & Sig. (2-tailed) & Mean diff. \\
\hline Prague & 44.28 & 12.17 & 48.04 & .000 & -3.76 \\
Královéhradecký Region & 44.60 & 12.14 & 48.66 & .000 & -4.06 \\
Pardubický Region & 43.20 & 12.20 & 48.13 & .000 & -4.93 \\
Plzeňský Region & 43.81 & 12.14 & 48.20 & .000 & -4.39 \\
Liberecký Region & 44.36 & 12.09 & 47.89 & .001 & -3.53 \\
Středočeský Region & 43.83 & 11.69 & 47.66 & .000 & -3.83 \\
Ústecký Region & 45.69 & 11.92 & 47.65 & .000 & -1.96 \\
Jihočeský Region & 44.64 & 12.24 & 48.26 & .000 & -3.62 \\
\hline Source: Research results & & & & & \\
\hline
\end{tabular}

Source: Research results. 
The test has shown that in all regions the $\mathrm{p}$ value is below 0.05 which indicates that we do not reject the null hypothesis and the mean age of debtors is significantly lower than the mean age of the population in each region. All regions show similar result with a slightly less significance in Liberecký and Ústecký regions.

For purposes of this research creditors were divided into three groups: Banking institutions, Non-Banking financial institutions and Others. As banking institutions were subdued all creditors that were licensed as bank by regulatory authorities. Among non-banking financial institutions are companies that specialized in customer loans and other financial institutions that are not licensed as banks. The group Others are entities that do not make their primary business on loans, such as state institutions, lawyers, doctors, insurance companies and all other subjects that do not fit in previous two categories.

According to Insolvency Act each debtor applying for debt relief must have at least two. In the table below is shown whether debtor owes money only to one type of creditor or more. It is not very common among the debtors who are undergoing the debt relief to be in debt only to one type of creditor, but if they do it is usually to banks, where they have mortgage in combination with consumer loans, or to many non-banking financial institutions, where they have many consumer loans. Except for Pardubický Region more than a half examined debtors owes money to all three types of creditor group. It is well known that people who have problems with their debts use another loans provided by non-banking institutions to repay their creditors, but consequently create a never ending circle of indebtedness which became only worse through the time.

Tab. 6 Diversity of creditors in regions (in \%)

\begin{tabular}{llll}
\hline Region & $\begin{array}{l}\text { Only 1 type } \\
\text { of creditor }\end{array}$ & $\begin{array}{l}\text { 2 types } \\
\text { of creditor }\end{array}$ & $\begin{array}{l}\text { All types } \\
\text { of creditors }\end{array}$ \\
\hline Prague & 6 & 39 & 55 \\
Královéhradecký Region & 4 & 46 & 50 \\
Pardubický Region & 5 & 60 & 35 \\
Plzeňský Region & 4 & 44 & 52 \\
Liberecký Region & 5 & 36 & 59 \\
Středočeský Region & 3 & 45 & 52 \\
Ústecký Region & 4 & 44 & 52 \\
Jihočeský Region & 5 & 34 & 61 \\
\hline Source: Research resutts
\end{tabular}

Source: Research results. 
Hospodka, J. - Buben, O. - Randáková, M. - Bokšová, J.: Personal Bankruptcy in the Czech Republic - Age and Gender of the Debtors and Structure of the Creditors.

Within the final table of this paper are proportions of each creditors group taking part in debtors' debts. Probably most abundant creditors group are Non-Banking financial institutions that, with exception of Prague, are taking part in debts of more than $90 \%$ of all debtor. On the other hand, there is an unexpectedly strong presence of Bank institutions, which are well known for cautious choosing of their clients. Therefore, it is surprising that among debtors undergoing personal bankruptcy is proportion of debtors owning money to Bank institutions just slightly lower or the same as to Non-Banking financial institutions.

As result of growing number of personal bankruptcies, which results in significant losses to creditors, a personal bankruptcy prediction system gained importance in last couple of years and is used in various models such as credit scoring and credit card data mining. (Xiong, 2013)

Tab. 7 Debtors usual type of creditor (in \%)

\begin{tabular}{llll}
\hline Region & $\begin{array}{l}\text { Bank } \\
\text { institutions }\end{array}$ & $\begin{array}{l}\text { Non-Banking } \\
\text { financial institutions }\end{array}$ & Others \\
\hline Prague & 88 & 88 & 73 \\
Královéhradecký Region & 85 & 91 & 70 \\
Pardubický Region & 85 & 91 & 62 \\
Plzeňský Region & 89 & 95 & 72 \\
Liberecký Region & 91 & 95 & 68 \\
Středočeský Region & 89 & 93 & 68 \\
Ústecký Region & 87 & 93 & 68 \\
Jihočeský Region & 89 & 92 & 75 \\
\hline Source: Research results & & &
\end{tabular}

Source: Research results.

\section{Conclusion}

According to the outcome of the research it is possible to assume that some types of creditors are more frequent than others and that vast majority of individuals who are applying for personal bankruptcy are indebted to more than one group of creditors. However, the research has indicated significant differences among particular groups of creditors and their frequency. The research has shown that, apart from Prague region, every region's non-banking financial institutions are creditors to more than $90 \%$ of debtors. On the other hand, the least represented group in all regions is Others. Despite the fact it is the least represented group, more than $60 \%$ of debtors in every region are indebted towards Others group. It is then to no surprise that Pardubický region is the only region with less than $50 \%$ of all debtors indebted towards less than 3 types of creditors. 
Also, the structure of debtors shows that some types of debtors are more frequent than others. The age group between 35 and 44 years of age stands out among others. Between this age people are most likely to become debtors. There is also some interesting information about the differences in structure of debtors age regarding the gender. When we consider both the gender and age, more male debtors are usually in lower age groups, whereas in higher age groups female debtors are more frequent. Lastly the difference between gender structure of inhabitants and gender structure of debtors is highest in Prague region with 8.8 percentage points.

Statistical tests regarding the age of debtors have shown that we do not reject the null hypothesis that the mean age of debtors is lower than the mean age of the population in each region adjusted for youngest and oldest inhabitants. Multiple reasons might cause this, such as that the oldest members of our society are quite fiscally conservative and do not end up in a position of being bankrupt. On the other hand, there might be plenty of debtors who are in an even worse position, who do not have sufficient means even to successfully apply for personal bankruptcy. As of this moment we have no data about such individuals as they were not covered by this research and it is therefore not possible to comment on that.

\section{References}

Czech National Bank, Czech Republic, 2016. Database ARAD. Available from: <http://www.cnb.cz/docs/ARADY/HTML/index.htm>. [21 August 2016].

Draghici, C., 2015. Insolvency of individuals in European legislation - Great Britain. In Law between modernization and tradition - implications for the legal, political, administrative and public order organization.

Frelichová, K., 2015. Debt relief or Personal bankruptcy. Aplikované parvo. Available from: <http://www.aplikovanepravo.cz/clanky-pdf/83.pdf>. [31 June 2016]

Hásová, J., Moravec, T., 2013. Insolvency Proceedings, C. H. Beck, Praha.

High Court decision in Prague of 11. 5. 2010, Sp. zn. KSPH 30 InS 2561/2010, 1VSPH 280/2010-A.

Hospodka, J., Maixner, J., Randáková, M., Bokšová, J., 2014. Personal Bankruptcy in the South Bohemian Region in the Czech Republic. In ALVER, J. (ed.). International Conference on Accounting, Auditing, and Taxation - ICAAT 2014. DEStech Publication, Inc., Pennsylvania.

Insolvency Act, 2008. (Law no. 182/2006 Sb.) MVCR, Prague.

Insolvency Register, 2014. Department of justice of Czech Republic 2014. Available from: <https://isir.justice.cz/>. [31 July 2014]. 
Hospodka, J. - Buben, O. - Randáková, M. - Bokšová, J.: Personal Bankruptcy in the Czech Republic - Age and Gender of the Debtors and Structure of the Creditors.

Jagtiani, J., Li, W., 2015. Credit access after consumer bankruptcy filing: New evidence. The American Bankruptcy Law Journal 2, 327-361. Available from: <http://search.proquest.com/docview/1697207057?accountid=17203>. [6 November 2016].

Paseková, M., 2013a. International advances in economic research: Personal Bankruptcy and its Social Implications. International Advances in Economic Research. Springer US. DOI: 10.1007/s11294-013-9410-7.

Paseková, M., 2013b. An analysis of the incidence of personal bankruptcy in the Moravian-Silesian Region in the Czech Republic. 6th International Scientific Conference on Finance and Performance of firms in Science, Education, and practice, 547-559. Tomas Bata University in Zlin, Czech Republic.

Paskevicius, A., Jurgaityte, N., 2015. Reason for Bankruptcy of Natural Persons in Lithuania. Ekonomika 2, 144-160. Available from: <http://search.proquest.com/ docview/1697563105? accountid=17203>. [6 November 2016].

Randáková, M., Bokšová, J., 2016. Bankruptcy of Individuals in the Czech Republic. In Proceedings ICABR. Mendel University in Brno, 2015, 460-469. Available from: <http://www.icabr.com/fullpapers/icabr2015.pdf>. [6 November 2016].

Roback, J., 1988. Wages, Rents, and Amenities: Differences among workers and regions. Economy Inquiry 1, 23-41. DOI: 10.1111/j.1465-7295.1988.tb011667.x.

Savu, A., 2016. The intersection of health and wealth: association between personal bankruptcy and myocardial infarction rates in Canada. In BMC Public Health. Vol. 15. DOI: 10.1186/s12889-016-2705-x.

Smrčka, L., 2011. The relation between indebtedness of the government, public sector and households in the Czech Republic. In E. Jircikova, E. Pastuszkova, \& J. Svoboda (EDS). 5th International Scientific Conference on Finance and the Performance of Firms in Science, Education, and Practice, 433-446. Tomas Bata University in Zlín, Czech Republic.

Xiong, T., 2013. Personal bankruptcy prediction by mining credit card data. Expert systems with applications 2, 665-676. DOI: 10.1016/j.eswa.2012.07.072. 